\title{
Population size, dynamics and reproduction success of the lesser spotted eagle (Aquila pomarina) in Latvia
}

\author{
Vel'kost' populácie, dynamika a reprodukčná úspešnost' orla krikl'avého (Aquila pomarina) \\ v Lotyšsku
}

\author{
Uǵis BERGMANIS, Ainārs AUNIŅŠ, Aivars PETRIŅŠ, Valdis CĪRULIS, Jānis GRANĀTS, \\ Otars OPERMANIS \& Andris SOMS
}

\begin{abstract}
We analysed the population size, population dynamics and reproduction success of the lesser spotted eagle in Latvia from 1988 to 2014. While the overall population did not show a statistically significant trend during any of the periods analysed (long, medium and short term), the populations in the individual study areas changed differently: of five research plots, populations were stable in two, increased in one, and decreased in two research plots. Using the existing research plots as samples of breeding numbers in areas of different breeding density classes based on forest management units, the total breeding population in Latvia was estimated. The overall number of breeding pairs in 2012-2014 was between 3700-4000. During the period 1988-2014, 65.62\% of all pairs recorded as present on their home range, made a breeding attempt and laid eggs. The reproductive success ratio was 0.49 young per occupied territory with an adult pair of birds and 0.74 young per breeding pair which laid eggs. Overall, during the 21-year research period there was a stable long-term trend in reproductive success (young per pair present on home range). Rarely, indeed only in $1.89 \%$ of all cases did two young fledge. The total number of young (young per $100 \mathrm{~km}^{2}$ ) shows stable long-, medium- and short-term trends with an average value of 5.1 young per $100 \mathrm{~km}^{2}$.
\end{abstract}

\begin{abstract}
Abstrakt: Analyzovali sme vel'kost' populácie, populačnú dynamiku a reprodukčnú úspešnost' orla krikl’avého v Lotyšsku od roku 1988 do roku 2014. Kým vel'kost' populácie ako celku nevykazovala štatisticky významný trend v priebehu žiadneho z analyzovaných období (dlhé, stredné a krátke), vel'kost' populácií v jednotlivých monitorovacích plochách varírovala: z piatich študijných plôch boli populácie stabilné $\mathrm{v}$ dvoch, nárast na jednej a pokles na dvoch študijných plochách. Na odhad počtu hniezdiacich párov v Lotyšsku sa použili údaje zo študijných plôch zaradených do tried podla hustoty hniezdnych párov pre lesné hospodárske celky. Celkový počet hniezdnych párov bol tak v rokoch $2012-2014$ približne $3700-4000$. V rokoch $1988-2014$ zahniezdilo $65,62 \%$ zaznamenaných teritoriálnych párov. Reprodukčná úspešnost' bola 0,49 mlád’ata na teritórium obsadené adultným párom a 0,74 mlád’ata na hniezdiaci pár, ktorý zniesol znášku. Celkovo bol počas 21 rokov výskumu zistený stabilný trend reprodukčnej úspešnosti (t.j. počet mlád’at na teritoriálny pár). Hniezdo opustili 2 mlád’atá len pri $1.89 \%$ hniezdení. Celkový počet mlád’at (na $100 \mathrm{~km}^{2}$ ) vykazoval stabilný dlho-, stredno- a krátkodobý trend a dosahoval hodnotu 5,1 mlád’ata na $100 \mathrm{~km}^{2}$.
\end{abstract}

Keywords: breeding density, reproductive success, population trends, sampling plots.

\footnotetext{
Ugíis Bergmanis (corresponding author), Joint Stock Company "Latvia's State Forests", address for correspondence: "Tiltakalni”, Barkavas pag., Madonas nov. LV-4834, Latvia. E-mail: u.bergmanis@1vm.lv.

Ainārs Auniṇš, Faculty of Biology, University of Latvia, Kronvalda bulv. 4, LV-1842, Latvia. E-mail: ainars.aunins@1u.lv.

Aivars Petriṇš, Museum of Zoology, University of Latvia, Kronvalda bulv. 4, LV1842, Latvia. E-mail: aivars.petrins@lu.lv.

Valdis Cīrulis, "Silenieki”, Sarkaņu pag., Madonas nov. LV-4870, Latvia. E-mail: ciinis@inbox.lv.

Jānis Granāts, "Robežnieki”, Birzgales pag., Ķeguma nov., LV-5033, Latvia. E-mail: janis.granats@gmail.com.

Otars Opermanis, Biota Ltd, Kr. Valdemāra iela 106/108-122, Rīga. LV-1013, Latvia. E-mail: opermanis@gmail.com.

Andris Soms, Nature Conservation Agency of Latvia, Rīgas iela 10a, Salacgrīva, LV-4033, Latvia. E-mail:

andris.soms@daba.gov.lv.
}

Acknowledgements: We thank Duncan Orr-Ewing and Thomas Krumenacker for their help in translating the manuscript into English. Rimgaudas Treinys, Jānis Reihmanis, Dāvis Drazdovskis, Ritvars Rekmanis are acknowledged for monitoring lesser spotted eagles in the research plots.

\section{Introduction}

The ongoing pressure on natural resources for human development, e.g. the intensification of agriculture, in- fluences and alters habitats. Thus it also causes an impact on the animal species that inhabit these areas. To assess this impact monitoring schemes have been un- 
dertaken in various countries (Vrezec et al. 2012). Since 2003 the ongoing programme to monitor biodiversity in Latvia has included coverage of the lesser spotted eagle (Aquila pomarina; LSE). Independently, research on the breeding density and the reproductive success of the species had already begun during the 1980s. Data collected over a long period of time using identical methodological standards allow an evaluation of the population trends of the LSE as well as an excellent estimate of the national population size.

The previous census of the LSE population was conducted in 2003 (Bergmanis et al. 2006), when the information obtained from plots was analysed in detail and the Latvian national population size for this species was first assessed on this basis. The present census provides an updated status of the national LSE population in Latvia and describes its development over different time periods. The study includes data from two new research plots as well as data from other plots that were not previously analysed. This work will result in improvements to our knowledge about the LSE population size, breeding density and trends in reproductive success in Latvia.

\section{Material and methods}

\section{S t u d y p lot s}

The data regarding numbers of breeding pairs, breeding density and reproductive success were gathered across six sample plots (Fig. 1, Tab. 1). "Murmastiene" and "Kemeri" have a significantly larger areas $\left(460 \mathrm{~km}^{2}\right.$ and $246 \mathrm{~km}^{2}$ respectively) because they have an atypical configuration: their central part is a large raised bog, which is not suitable or at least not typical habitat for the LSE. Plots "Pāle" and "Mazgramzda" were chosen on a random basis (the only limiting criterion was to have a plot in the NE and the SW parts of the country). Locations of the other three plots were influenced by the practicalities of being situated close to the homes of key species experts.

In addition, for the period 2007 to 2011, data regarding reproductive success were also gathered in sites situated in the midst of "Murmastiene" and "Žūklis" research plots (described as "KSD" - Kuja, Saikava, Degumnieki).

\section{D a t a co 11 e c t i o}

Eagle censuses in plots were carried out over two periods. The first survey was from mid-April till May 10, at a time when the eagles have just arrived back to Latvia from their wintering grounds. The birds are actively displaying on occupied home ranges and thus are conspicuous and easy to record. During this first survey, we confirmed occupied territories and, where possible, also located nests since during the period when there are no leaves on the trees they are easier to find. The whole plot area was observed visually to confirm displaying birds or by hearing typical calls from forest near the

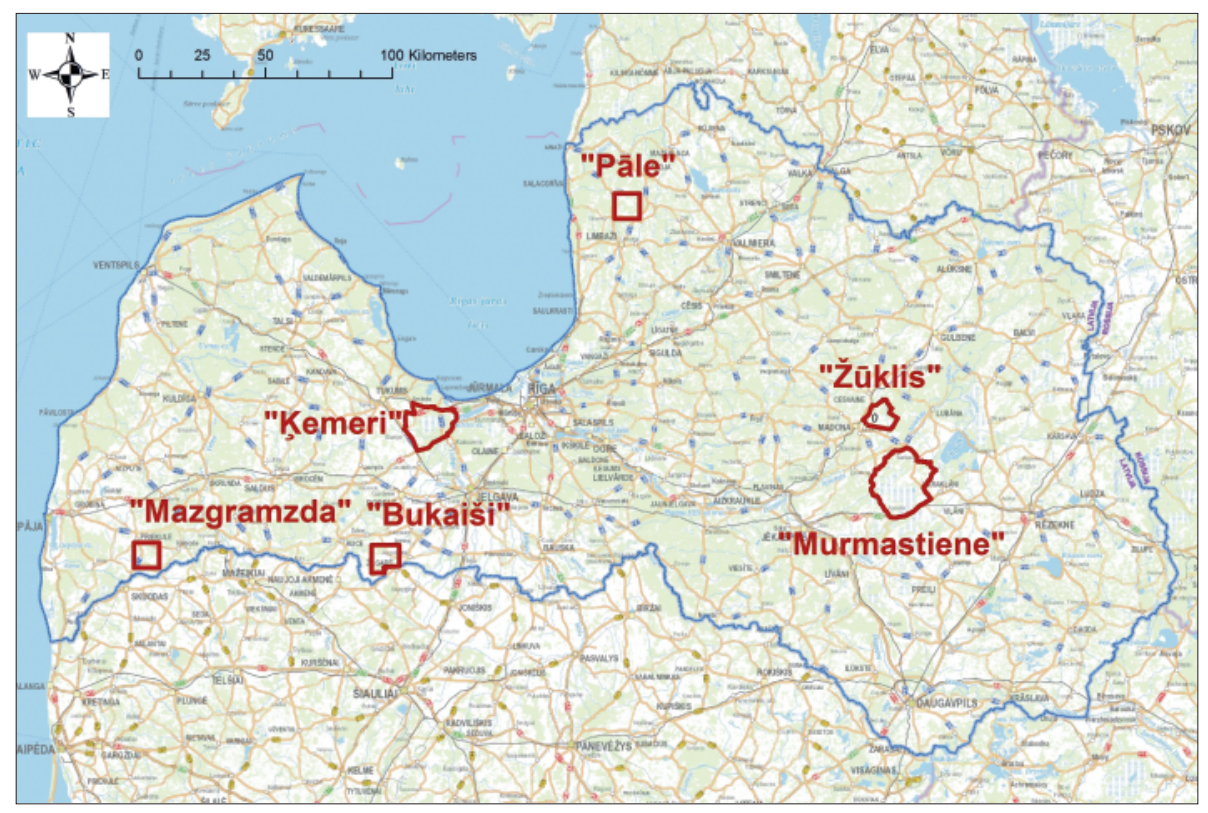

Fig. 1. Location of sampling survey plots for the lesser spotted eagle in Latvia.

Obr. 1. Umiestnenie monitorovacích plôch pre orla kriklavého v Lotyšsku. 
Tab. 1. Characteristic features of sampling plots for the lesser spotted eagle. Source of data: Corine Land Cover, European Environment Agency (2012).

Tab. 1. Charakteristika monitorovacích plôch pre orla kriklavého. Zdroj dát: Corine Land Cover, European Environment Agency (2012).

\begin{tabular}{|c|c|c|c|c|c|c|}
\hline $\begin{array}{l}\text { land cover type / } \\
\text { druh krajinnej pokrývky }\end{array}$ & Murmastiene & Žūklis & Bukaiši & Pāle & Mazgramzda & Kemeri \\
\hline area $\left(\mathrm{km}^{2}\right)$ / výmera & 460 & 94 & 106 & 100 & 100 & 246 \\
\hline farmland (\%) / pol'nohosp. pôda & 37 & 51 & 67 & 45 & 54 & 25 \\
\hline forest $(\%) /$ les & 24 & 39 & 23 & 31 & 30 & 42 \\
\hline woodland/shrub (\%) / riedke lesy, kroviny & 11 & 11 & 9 & 23 & 15 & 11 \\
\hline peatbogs (\%) / rašeliniská & 27 & 0 & 0 & 0 & 0 & 19 \\
\hline others (\%) / ostatné & 1 & 0 & 1 & 1 & 1 & 3 \\
\hline altitude (m a.s.I.) / nadm. výška (m n. m.) & $91-115$ & $93-118$ & $60-85$ & $52-91$ & $26-130$ & $24-35$ \\
\hline study period / sledované obdobie & 1994-2014 & 2002-2014 & 1988-2014 & 2007-2014 & $\begin{array}{l}\text { 2008-2009, } \\
2012-2014\end{array}$ & 2002-2003 \\
\hline
\end{tabular}

nest. In cases where a nest was located, the territory was immediately left by observers, and the content of nests was not checked during the spring census. Visual observations were aided by the use of telescopes and/or binoculars and were done from good observation points such as open spaces, high elevations and sometimes also buildings or trees. Observation points were planned to cover the whole sample plot area to allow optimum search for eagles within a $2 \mathrm{~km}$ radius around each point. Each observation point was served by one observer, usually spending $2.5-3 \mathrm{hrs}$ there. If a breeding territory was located in a shorter period, the surveyor moved to the next observation point paying attention to other potential territories.

The second census started out from the second half of June (when adults are more frequently carrying food to the nest) and continued till mid-August when most juveniles leave the nest. During these surveys, the status of the birds/pairs observed in spring were followed up on the ground, and it was confirmed whether they should be assigned as breeding category (young in the nest), or evidence of unsuccessful breeding (unhatched eggs or egg remains); or territorial pair category (nest improved, feathers). In addition, we also checked unoccupied and potential territories (based upon the results from the current year spring survey or from previous years). In this survey all nests were climbed for careful examination.

Overall, the most productive time for LSE observations was between 08:00-14:00 and between 16:00-19:00. The best weather was sunny, warm and windy conditions: on such days the eagles actively flew, displayed and hunted all day long. In cool and rainy conditions, as well as on hot days with temperatures over $27^{\circ} \mathrm{C}$, the activity of the birds was much less and the survey may therefore be biased or require further survey effort.

Observations in each plot were carried out by $1-4$ qualified observers. The average effort necessary to conduct one full check of one plot $\left(\sim 100 \mathrm{~km}^{2}\right)$ with $10-15$ breeding pairs is approximately 25 man-days, or 200 man-hours with higher LSE densities, e.g. in the case of over 15 pairs and up to 30 pairs, the required effort could amount to as much as 40 man-days.

\section{B r e e ding density and popula-} $\mathrm{t}$ i o $\mathrm{n}$ tre $\mathrm{nd} \mathrm{s}$

The breeding density was calculated as number of pairs present per $100 \mathrm{~km}^{2}$. The category "pair present" describes the sum of breeding pairs, territorial pairs and pairs whose status is unknown.

We defined pairs as "breeding pairs" if we found chick(s) or at least egg(s) in their nests. This definition also provides for pairs where we could not find a nest, but observed the food delivery to a nest or where fledged young were located. "Territorial pairs" are those pairs for which a nest is known but no chick(s) or clutch was found during nest controls. "Pairs with unknown breeding status" are those pairs where no breeding success could be established due to the fact that the nest site was not located, or pairs that were not successfully breeding in known nests that were not inspected closely because they were not climbed for inspection of their contents. Excluded from our calculation of the pairs present were single territorial birds.

Given the different lengths of observation periods in plots, changes in the population were analysed in three periods: 1994-2014 (long-term, data from "Bukaši" and "Murmastiene"); 2002-2014 (medium-term, data from "Bukaiši”, "Murmastiene" and "Žūklis"); and 


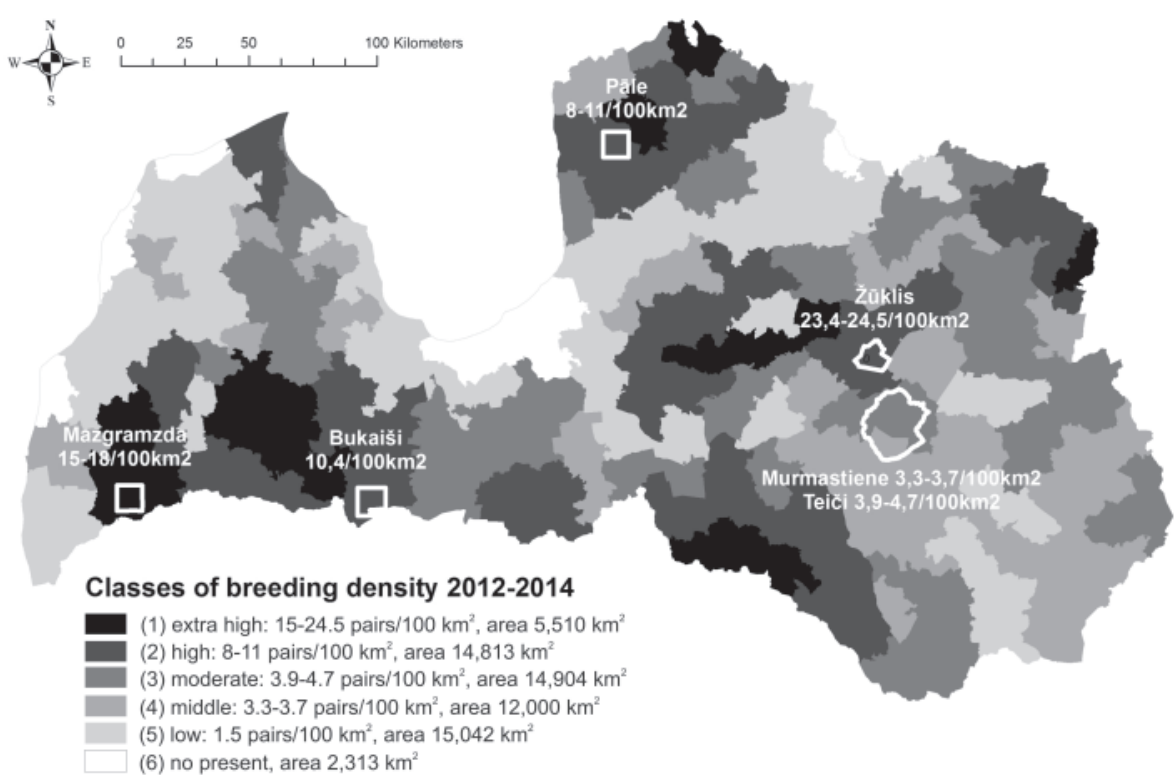

Fig. 2. Division of Latvia according to forest management units with different evaluated breeding density of lesser spotted eagle in 2012-2014

Obr. 2. Rozdelenie Lotyšska na základe lesných hospodárskych celkov s rôzne stanovenou hniezdnou hustotou orla kriklavého v rokoch 2012 - 2014.

Triedy hniezdnej hustoty: (1) extra vysoká: 15 - 24,5 p/100 km², výmera 5510 km2, (2) vysoká: 8 $11 \mathrm{p} / 100 \mathrm{~km} 2$, výmera 14813 $\mathrm{km}^{2}$, (3) mierna: $3,9-4,7 \mathrm{p} / 100$ $\mathrm{km}^{2}$, výmera $14904 \mathrm{~km}^{2}$, (4) stredná: 3,3 - 3,7 p/100 km², výmera 12000 km², (5) nízka: 1,5 $\mathrm{p} / 100 \mathrm{~km}^{2}$, výmera $15042 \mathrm{~km}^{2}$, (6) druh neprítomný, výmera 2313 $\mathrm{km}^{2}$.
2007-2014 (short-term, data from "Bukaiši", "Murmastiene", "Žūklis" and "Pāle").

\section{P o p u 1 a t i o n si z e}

The estimate of the total population size of the LSE in Latvia was based on population density in different classes (the class division is based on different breeding densities in plots) of forest management units using the approach described in Bergmanis et al. (2006). All 199 "forest management units" (administrative territories of forestries, defined in the year 2000, State Forest Service of Latvia) comprising a total surface of $64,581 \mathrm{~km}^{2}$, were assigned to one of five classes of breeding density (Fig. 2). We used the same classification of forest management units and density classes as in Bergmanis et al. (2006) since they had not changed during this period.

The new population size estimate is based on full datasets from seven research plots (sample plot "Teiči" with an area of $128 \mathrm{~km}^{2}$ since 1994 completely included in the sample plot "Murmastiene") in the period 1988-2014 (Tab. 1). Compared to the previous study (Bergmanis et al. 2006), the study plots "Zvārde" and "Vecumi" were excluded from calculations as no surveys had been conducted there since 2004. Instead the newly established plots "Pāle" and "Mazgramzda" were used. Although already established 2007 and 2008, in "Mazgramzda" no counts were conducted in 2010 and 2011.

The research plots were used as samples of the less- er spotted eagle numbers in each of the density classes. Each of them was assigned to one of the density classes. The area of each research plot and area of the territory of the corresponding density classes in the country as well as number of research plots per particular density class was used to obtain the weight for each research study plot. These weights were used in TRIM analysis to obtain imputed time totals corresponding to the estimated population size in the country.

The definitions of the five density classes, the total surface area of every class and calculations applied are given below (see also Fig. 2).

Extra high density: $15-24.5$ pairs $/ 100 \mathrm{~km}^{2}$, total area $5,510 \mathrm{~km}^{2}$. Data from sampling plots "Žūklis", "Mazgramzda" used. The research plot "Mazgramzda" was only established in 2008 while "Žūklis" originated in 2002.

High density: $8-11$ pairs $/ 100 \mathrm{~km}^{2}$, total area 14,813 $\mathrm{km}^{2}$. Data from sampling plots "Bukaiši", "Pāle". The sample plot "Pāle" was also established in 2007.

Moderate: $3.9-4.7$ pairs $/ 100 \mathrm{~km}^{2}$, total area 14,904 $\mathrm{km}^{2}$ (data from sample plot "Teiči", since 1994 completely included in the sample plot "Murmastiene").

Middle: $3.3-3.7$ pairs $/ 100 \mathrm{~km}^{2}$, total area 12,000 $\mathrm{km}^{2}$ (data from sample plot "Murmastiene").

Low: 1.5 pairs $/ 100 \mathrm{~km}^{2}$, total area $15,042 \mathrm{~km}^{2}$ (data from sample plot "Kemeri"). Counts in this research plot took place only in 2002-2003.

Not present: total area $2,313 \mathrm{~km}^{2}$. Areas without any 
presence of LSE are mostly larger pine forest adjacent to the Baltic Sea and also the city of Riga and its surroundings.

A disadvantage of the structuring of forest management units in density classes is that this has been done without GIS supported analysis, but instead by visual analysis of forest maps and recommendations based on the experience of the researchers. Knowing about the habitat requirements of the LSE, we took the following principle as a basis: the smaller the percentage of large and connected pine tree forests and the larger the percentage of tessellated extension of forests and the bigger the percentage of grown deciduous and mixed forests, the higher the breeding density that can be expected.

Re productive s u c c e s s

Reproductive success is calculated as the number of young per pair present; young per breeding pair; and young per $100 \mathrm{~km}^{2}$. Reproductive success taken as young per pair present represents the number of young birds in comparison to the number of pairs present. This is a suitable parameter to characterise those parts of the population of which the density is unknown (populations outside the sample plots). The indication of reproductive success by young per $100 \mathrm{~km}^{2}$ is a more objective parameter as it represents the total number of young in relation to the area (for example, 4 young from 8 pairs in a plot produces reproductive success 0.5 young per pair present. If in the same plot the number of pairs decreases by half, and from these 4 pairs only 2 juveniles leave nests, reproductive success is still 0.5 young per pair present. Such a calculation does not indicate a decrease, but this can be improved if breeding success is calculated as young per $\mathrm{km}^{2}$ ).

The nest inspections are conducted from July 5 to July 25 , a period in which the eaglets are fully or at least partly feathered. To calculate the proportion of breeding pairs/territorial pairs, those pairs with unknown breeding status were not included.

\section{D a t a a n a 1 y s is}

Spearman rank correlation was used to assess the relation between a parameter value and time (year) for each study area using R software version 3.1.0 (R Core Team 2014).

To assess the overall population size, calculate trends and change in the population size, density and reproductive output in multiple study areas as well as to obtain year specific estimates, TRIM program version 3.54 (Pannekoek \& van Strien 2005) was used.

\section{Results}

B reeding de nsity a nd popula$\mathrm{t}$ i o $\mathrm{n}$ tre $\mathrm{nd} \mathrm{s}$

The breeding density and population dynamics differ in the studied sample plots as indicated in Tab. 2; Fig. 3.

The highest breeding density was found in the sample plot "Žūklis" (21.3-33.0 pairs/100 $\mathrm{km}^{2}$ 2002-2014), however there was a decline during the study period (2002-2014; Spearman rank correlation: $\mathrm{R}_{\mathrm{S}}=-0.59, \mathrm{P}=0.032$ ). This decline was most pronounced until 2005, and the population size reached its lowest point in 2007 with 21.3 pairs $/ 100 \mathrm{~km}^{2}$. After the decline the breeding density stabilised at values between 21.3-26.6 pairs $/ 100 \mathrm{~km}^{2}$ during the period $2005-2014$ (Spearman rank correlation: $\mathrm{R}_{\mathrm{S}}=-0.11, \mathrm{P}=0.76$ ). The average breeding density for the years 2005-2014 (23.9 pairs $/ 100 \mathrm{~km}^{2}$ ) showed a decline by $28 \%$ compared to the peak year 2003 (33 pairs $/ 100 \mathrm{~km}^{2}$ ).

In the adjacent sample plot of "Murmastiene" (2.2-3.7 pairs $/ 100 \mathrm{~km}^{2}$ in 1994-2014) we found a decline from 3.5 pairs $/ 100 \mathrm{~km}^{2}$ during the peak years $1999-2000$ to 2.2 pairs $/ 100 \mathrm{~km}^{2}$ in 2003 . The breeding density stabilised thereafter, and in 2014 we recorded the highest breeding density of the entire period ( 3.7 pairs $/ 100 \mathrm{~km}^{2}$ ). The entire trend over the full period (1994-2014) is therefore stable (Spearman rank correlation: $\mathrm{R}_{\mathrm{S}}=0.14, \mathrm{P}=0.54$ ). A tendency to re-colonise lost territories can be identified, and new territories have been established.

A stable trend (Spearman rank correlation: $\left.R_{S}=-0.15, P>0.46\right)$ was also found in the sample plot "Bukaiši" (8.5-12.3 pairs/100 $\mathrm{km}^{2}$ ) for the period 1988-2014 with 9.4-10.4 pairs/100 km² since 1999.

In both new sample plots "Pāle" and "Mazgramzda", representing different parts of the West and North of Latvia, we found high breeding densities but different dynamics. In "Pāle" (8-13 pairs/100 km² in 2007-2014) a near-significant decreasing trend (Spearman rank correlation: $\mathrm{R}_{\mathrm{S}}=-0.61, \mathrm{P}=0.10$ ) was observed, whereas the breeding density in "Mazgramzda" (12-18 pairs/100 $\mathrm{km}^{2}$ in 2008-2014) increased (Spearman rank correlation: $\mathrm{R}_{\mathrm{S}}=0.90, \mathrm{P}=0.037$ ).

Thus, of the five sample plots, a stable trend in breeding density was established in two; an increase in one; and a decrease in two research plots. 


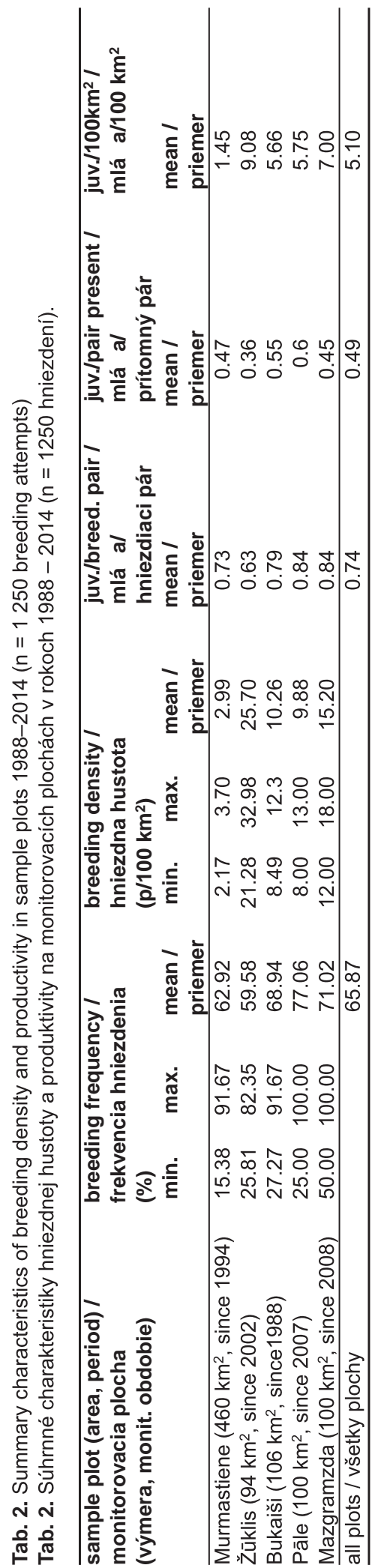

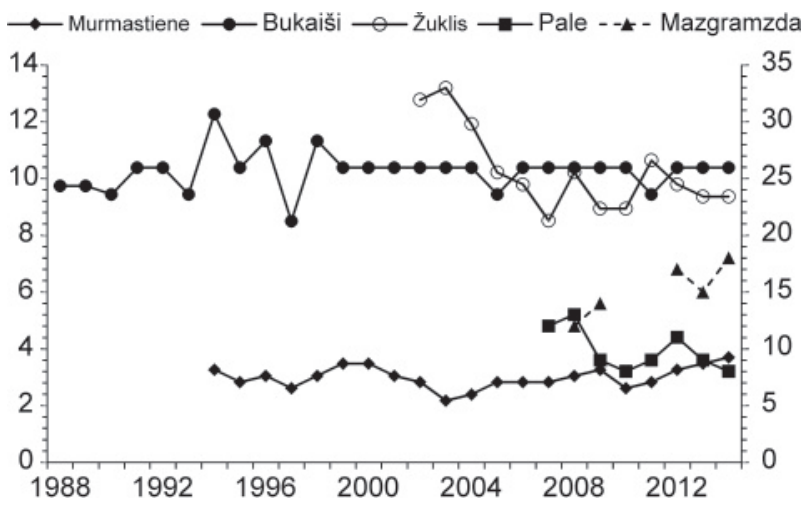

Fig. 3. Changes in numbers of lesser spotted eagles in different sample plots (pairs present/100 km²). Left y-axis: "Murmastiene", "Bukaiši", right y-axis: "Žūklis", "Pāle", "Mazgramzda".

Obr. 3. Zmeny početnosti orla kriklavého na monitorovacích plochách (prítomné páry/100 km²). L'avá os Y: "Murmastiene", "Bukaiši", pravá os Y: "Žūklis", "Pāle", "Mazgramzda".

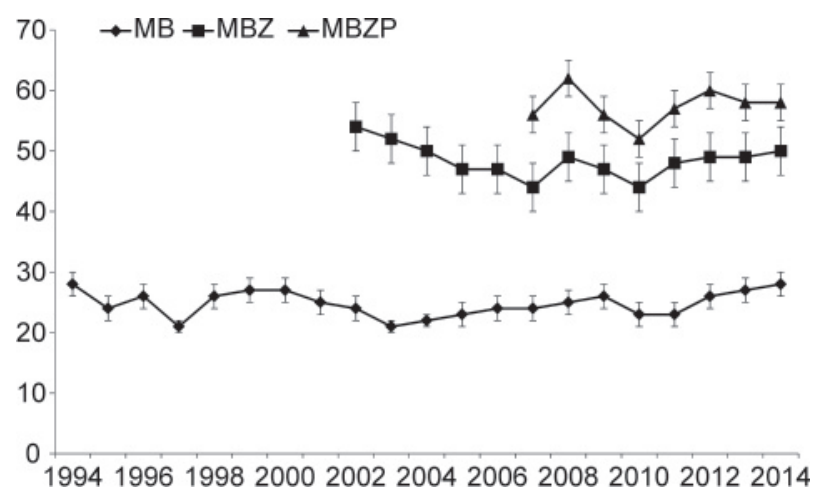

Fig. 4. Trends in numbers of lesser spotted eagles (pairs present) in different time periods: MB ("Murmastiene", "Bukaiši" 1994-2014), MBZ ("Murmastiene", "Bukaiši", "Žūklis" 2002-2014) and MBZP ("Murmastiene", "Bukaiši", "Žūklis", "Pāle" 2007-2014). Whiskers indicate standard error.

Obr. 4. Trend početnosti orla kriklavého (prítomné páry) v rôznych obdobiach: MB ("Murmastiene", "Bukaiši" 1994-2014), MBZ ("Murmastiene", "Bukaiši", "Žūklis" 2002-2014) a MBZP ("Murmastiene", "Bukaiši", "Žūklis", "Pāle" 2007-2014). Úsečky zobrazujú štandardnú chybu.

To calculate the population trends for different time periods, TRIM models using the data from the research plots that were surveyed in the same period of time were constructed for the different time periods (Fig. 4). The 20 -year long-term trend ("Murmastiene" and "Bukaiši" 1994-2014) is stable (trend \pm standard error: $1.0006 \pm$ 0.0027). Despite the significant decrease in the breeding population in the "Zūklis" plot, the overall 12-year trend in the 3 study areas ("Murmastiene", "Bukaiši" and 


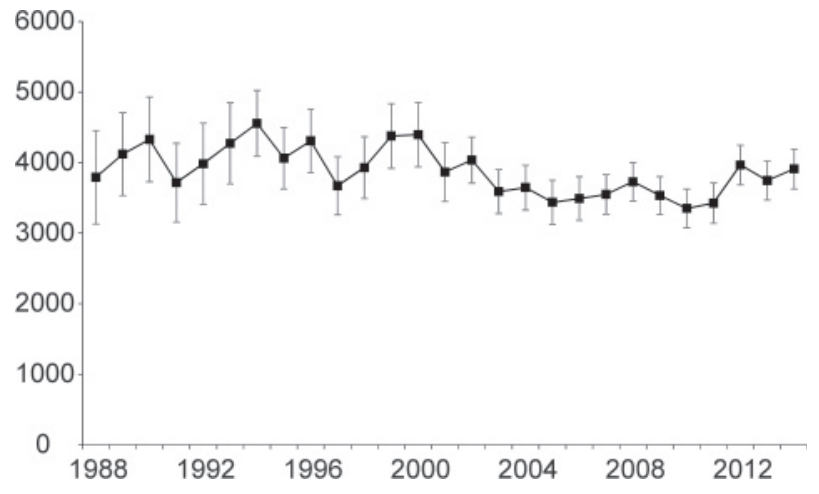

Fig. 5. Changes in the estimated population size of the lesser spotted eagle in Latvia. Whiskers indicate standard error.

Obr. 5. Zmeny $v$ odhadovanej vel'kosti populácie orla kriklavého v Lotyšsku. Úsečky zobrazujú štandardnú chybu.

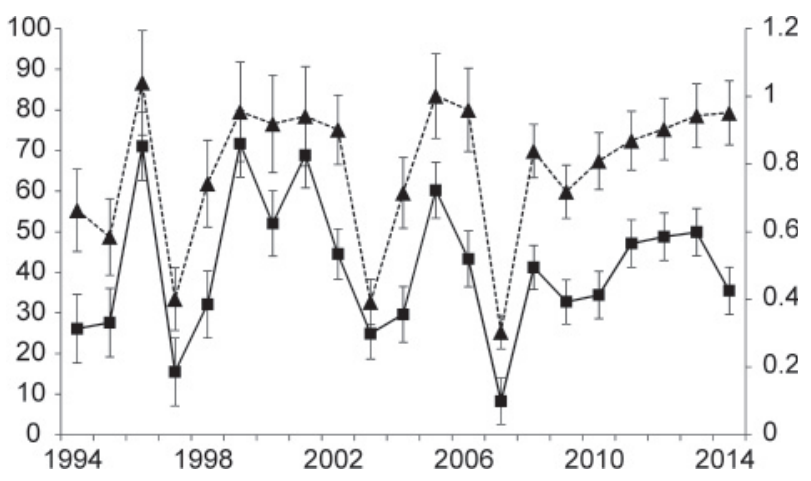

Fig. 6. Characteristics of reproductive success of the lesser spotted eagle in the sample plots "Murmastiene", "Bukaiši", "Žūklis", "Pāle", "Mazgramzda" and "KSD". Left y-axis and triangles with dashed line: breeding frequency, right $y$-axis and squares with solid line:juveniles/pair present. Whiskers indicate standard error.

Obr. 6. Charakteristiky reprodukčnej úspešnosti orla krikl'avého na monitorovacích plochách "Murmastiene", "Bukaiši", "Žūklis", "Pāle", "Mazgramzda" a "KSD". L'avá os Y a trojuholníky s prerušovanou čiarou: frekvencia hniezdenia, pravá os $Y$ a štvorce s plnou čiarou: počet mlád'at/prítomný pár. Úsečky zobrazujú štandardnú chybu.

“Žūklis" 2002-2014) remained stable (trend \pm standard error: $0.9954 \pm 0.0077)$. The 7 -year short-term trend in the 4 study plots ("Murmastiene", "Bukaiši”, "Žūklis" and "Pāle" 2007-2014) also shows a stable tendency (trend \pm standard error: $1.0025 \pm 0.0096$ ).

P o p u lat i o n s i z e

The TRIM model-based calculations of the Latvian population of the lesser spotted eagle suggests that it fell to between 3,700 and 4,000 pairs in 2012-2014. Although the overall population during the whole study period (1988-2014) did not change significantly (trend \pm standard error: $0.9940 \pm 0.1157$ ), some periods with high and low population can be spotted (Fig. 5). The population reached peaks in 1995 and 1999-2000 when it was estimated above or close to 4,400 and then decreased to reach a minimum during the period of 2005 and 2011, when in all years except one the estimated population was below 3,500 pairs. Since the all-time minimum in 2010 a slow recovery of the population can be observed.

\section{Reproductive suces s}

The reproductive success in relation to pairs present and per breeding pair (young per pair present and young per breeding pair) indicates the success of the pairs present in the various areas. During the research period 1988-2014 $65.62 \%$ of all surveyed pairs started breeding $(\mathrm{n}=1,178$ analysed breeding attempts). The average reproductive success ratio was 0.49 young per pair present ( $\mathrm{n}=1,250$ analysed breeding attempts) and 0.74 young per breeding pair ( $\mathrm{n}=719$ analysed breeding attempts). During the 21-year research period (1994-2014) a stable long-term trend of reproductive success is shown (trend \pm standard error: $1.044 \pm$ 0.0082 , Fig. 6). Rarely, only in $1.89 \%$ of all cases, did two young fledge ( $\mathrm{n}=474$ analysed successful breeding attempts).

A more robust parameter of reproductive success in areas with constant size is the number of young birds in relation to the size of the area (young per $100 \mathrm{~km}^{2}$ ), as this also includes fluctuations in the numbers of pairs present. The total number of young that may have fledged from sample plots with a constant size shows a stable long-term (1994-2014) and medium-term (2002-2014) trend (trend \pm standard error: $0.9999 \pm$ 0.0177 and $1.0080 \pm 0.0176$ ), and a statistically nonsignificant short-term (2008-2014) trend (trend \pm standard error: $1.0418 \pm 0.0335$; Fig. 7). Overall estimated relative breeding output (young per $100 \mathrm{~km}^{2}$ ) of the LSE over the whole study period, assuming variability of the parameter among the different sample plots, was stable $(\mathrm{S}=1.0013 \pm 0.0109$; Fig. 8$)$. Of the sample plots with different breeding densities on average 1.45 (Murmastiene), 5.66 (Bukaiši), 5.75 (Pāle), 7 (Mazgramzda) and 9.08 (Žūklis) young per $100 \mathrm{~km}^{2}$ fledged (median value $5.1 / 100 \mathrm{~km}^{2}$ ). Furthermore we lack information from plots with low breeding density. 


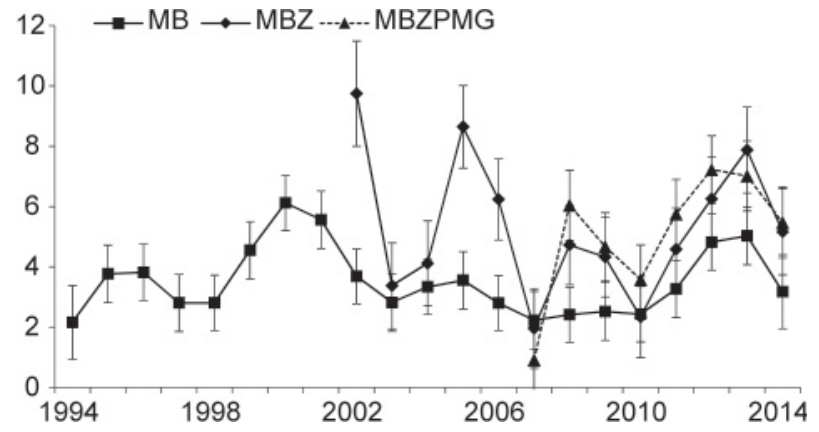

Fig. 7. Characteristics of breeding output of the lesser spotted eagle (juv./100 $\left.\mathrm{km}^{2}\right)$ in the sample plots in different periods $(\mathrm{M}-$ "Murmastiene", B - "Bukaiši", Ž - "Žūklis", P - "Pāle", MG "Mazgramzda"). Whiskers indicate standard error.

Obr. 7. Charakteristiky hniezdenia orla kriklavého (juv./100 km²) na monitorovacích plochách $v$ rôznych obdobiach (M - "Murmastiene", B - "Bukaiši", Ž - "Žūklis", P - "Pāle", MG - "Mazgramzda"). Úsečky zobrazujú štandardnú chybu.

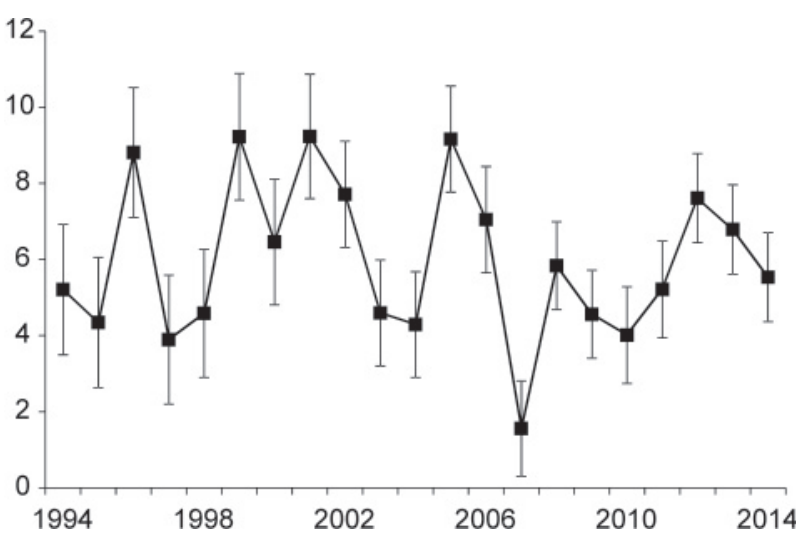

Fig. 8. Overall estimated relative breeding output of the lesser spotted eagle (juv./100 $\mathrm{km}^{2}$ ) in all research plots over the whole study period. Whiskers indicate standard error.

Obr. 8. Celkový odhad relatívnych výsledkov hniezdenia orla kriklavého (juv./100 km²) na všetkých monitorovacích plochách počas celého obdobia monitoringu. Úsečky zobrazujú štandardnú chybu.

\section{Discussion}

Population dy a mics

a $\mathrm{n} \mathrm{d}$ s i z e

Research on the LSE over the last eleven years has resulted in the emergence of new valuable information with regard to the breeding density of this species in several parts of the country, as well as regarding the overall population trends and the population size.

With an estimated population size of approx. 3,800 pairs in most recent years, Latvia together with the neighbouring countries of Belarus $(3,200-3,800$ pairs, Dombrovski \& Ivanovski 2005); Lithuania (1,900-2,900 pairs, Treinys unpubl. data); Estonia (600-700 pairs, Väli 2015) and Poland (2,283-2,739 pairs, Mirski et al. 2013) forms the core range of this species.

In none of the research plots could we confirm the highest densities found in the years 2002/2003 with 3233 pairs $/ 100 \mathrm{~km}^{2}$ in Žŭklis. The breeding density in this plot decreased to $21.3-26.6$ pairs $/ 100 \mathrm{~km}^{2}$ in the period 2005-2014. The breeding densities in the newly-established sample plots of Pāle (surveyed since 2007, 8-13 pairs $/ 100 \mathrm{~km}^{2}$ ) and Mazgramzda (surveyed since 2008, $12-18$ pairs $/ 100 \mathrm{~km}^{2}$ ) roughly correspond to the densities predicted in the respective forest management units (Bergmanis et al. 2006). High breeding densities are also known from parts of Belarus neighbouring Latvia to the south and south-east with $7.5-10.9$ pairs $/ 100 \mathrm{~km}^{2}$ (Dombrovski et al. 2001), locally up to 20 pairs $/ 100 \mathrm{~km}^{2}$ (Dombrovski \& Ivanovski 2005). High densities also occur in parts of Poland (more than 10 pairs $/ 100 \mathrm{~km}^{2}$ ), although on average 1-5 pairs $/ 100 \mathrm{~km}^{2}$ breed (Mirski et al. 2013). In contrast, in the westernmost expanse of the range of the species in north-east Germany in the state of Mecklenburg - Pomerania the breeding density is considerably lower, at about 1.4 pairs $/ 100 \mathrm{~km}^{2}$ (Scheller et al. 2001). The status of the population of the lesser spotted eagle differs over the different time-periods and the different parts of its range. The Latvian population underwent a decline in the period 2003-2011. This effect was most likely the result of the intensification of agriculture/forestry that has taken place in all parts of the country since the turn of the millennium. A decline of $26 \%$ as a result of more intensive forest systems was also identified in Lithuania during the period from 1980-2006 (Treinys et al. 2007). However, in Estonia, situated on the northern periphery of the range, no decline was detected and the overall trend over the last two decades is stable (Väli 2015). In Germany - the westernmost part of the range of the species - an ongoing decline in pairs/present was established (up to $23 \%$ in the period from 1993-2007). This negative trend was related to the ongoing fragmentation and destruction of suitable habitats as well as human disturbance in breeding home ranges (Meyburg et al. 2008, Böhner \& Langgemach 2004, Langgemach \& Böhner 2011). Corresponding to the significant decline in the number of breeding pairs in Germany, there has also been a steady 
loss of suitable habitat. Since 1800 it is estimated that $90 \%$ of suitable habitats in Germany have been destroyed (Meyburg et al. 2008). In the state of Mecklenburg-Pomerania (which has the largest proportion of the LSE population in Germany) between 1970 and 2001 about $7.7 \%$ of suitable habitats were destroyed (Scheller et al. 2001).

Despite home range losses and the decline in pairs/present in some parts of its native range, the population trend of the LSE in the core parts of its range is stable. This is indicated by counts during the autumn migration of the lesser spotted eagle in Israel conducted annually by the Israeli BirdLife Partner Israeli Ornithological Center (IOC). For example, in 2010 a total of 124,000 lesser spotted eagles were counted, the second highest number since the beginning of the counts in the 1980s. The most recent count in the autumn of 2014 resulted in 109,200 birds being counted, which represents the fourth highest total number ever counted. This supports the theory of a stable population at least in the core breeding areas (Krumenacker 2012 and pers. comment).

\section{R e p r o d u c t i ve suc ce s s}

The reproductive success of the LSE is influenced mainly by biotic (food), abiotic (climate) and anthropogenic (human disturbance) factors in the breeding territories. The most important single factor is the availability of food, which depends on climatic factors that determine the size of prey species populations (Lõhmus \& Väli 2004, Treinys \& Dementavičius 2004, Bergmanis et al. 2006, Väli 2012, Scheller et al. 2001). Stable breeding success over a long period of time also secures stable development of the population.

In our research the ratio of pairs that were breeding increased from 58\% in 1988-2003 (Bergmanis et al. $2006)$ to $66 \%$ in $1988-2014$. This increase can most likely be explained by greater availability of data. The established value corresponds with findings in Estonia (69\%, Väli 2012) but is lower than in MecklenburgPomerania (78\%, Scheller et al. 2001). The long-term value for breeding success 0.49 juv./pair present is lower than in Estonia (0.56 juv./pair, Väli 2012), Lithuania (0.60 juv./pair, Treinys 2009), the German states of Brandenburg ( 0.65 juv./pair, Böhner \& Langgemach 2004) or of Mecklenburg-Pomerania (0.51 juv./pair, Scheller et al. 2001) and Poland (0.69 juv./pair, Mirski et al. 2013). In practice the real ratio will be lower because in the time period between the nest inspection and the actual fledging of the chicks in early August, some young will fall victim to natural predators.

In spite of the typical phenomenon of cainism, occasionally two chicks are raised. Between 1980 and 1996 we found that $2.5 \%$ of successful pairs $(\mathrm{n}=118$ successful breeding attempts) raised 2 chicks (Bergmanis et al. 2001). This ratio changed to $1.58 \%$ in the research period 1984-2014 (9 cases out of 570 successful pairs). This decline can probably be explained once again by a greater amount of available data. This ratio is similar to Estonia (1.86\%, Väli 2012), but smaller than in Lithuania (2.4\%, Treinys 2009) or in the Slovak Republic (3.61\%, Maderič et al. 2008).

\section{References}

Bergmanis U, Petriņš A \& Strazds M 2001: The number, distribution and breeding results of the lesser spotted eagle Aquila pomarina in Latvia. Acta Ornithoecologica 4 (2-4): 305-319.

Bergmanis U, Petriņš A, Cīrulis V, Matusiak J \& Ķuze J 2006: Lesser spotted eagle Aquila pomarina in Latvia - current status, endangerment and perspectives. Populationsökologie Greifvogel- und Eulenarten 5: 95-115.

Böhner J \& Langgemach T 2004: Warum kommt es auf jeden einzelnen Schreiadler Aquila pomarina in Brandenburg an? Ergebnisse einer Populationsmodellierung. Vogelwelt 125: 271-281.

Dombrovski VC \& Ivanovski VV 2005: New data on numbers and distribution of birds of prey in Belarus. Acta Zoologica Lituanica. 15: 218-227. DOI: 10.1080/13921657.2005.10512615.

Krumenacker T 2012: Der Durchzug von Schreiadlern Aquila pomarina, Wespenbussard Pernis apivorus, Kurzfangsperber Accipiter brevipes, Weißstorch Ciconia ciconia und Rosapelikan Pelecanus onocrotalus über Nordisrael - eine Bilanz aus 30 Jahren. Limicola 26: 161-237.

Langgemach T \& Böhner J 2011: Modellierung der Populationsdynamik des Schreiadlers Aquila pomarina in Brandenburg: Welchen Effekt haben Jahre mit extrem niedriger Reproduktion? Vogelwelt 132: 93-100.

Lõhmus A \& Väli Ü 2004: The effects of habitat quality and female size on the productivity of the lesser spotted eagle Aquila pomarina in the light of the alternative prey hypothesis. Journal of Avian Biology 35: 455-464. DOI: 10.1111/j.0908-8857.2004.03228.x. 
Maderič B, Danko Š \& Dravecký M 2008: Records of the lesser spotted eagle (Aquila pomarina) nests with two fledged young without human intervention in Slovakia. Slovak Raptor Journal 2: 19-26. DOI: 10.2478/v10262-012-0015-5.

Meyburg B-U, Graszynski K, Langgemach T, Sömmer P \& Bergmanis U 2008: Cainism, nestling management in Germany in 2004-2007 and satellite tracking of juveniles in the lesser spotted eagle (Aquila pomarina). Slovak Raptor Journal 2: 53-72. DOI: 10.2478/v10262-012-0015-5,

Mirski P, Cenian Z, Wojciak J, Zawadzka D, Lontkowski J \& Stój M 2013. Lesser spotted eagle national action plan for Poland. Draft version. Olsztyn, Eagle Conservation Committee, 118.

Pannejoek J \& van Strien A 2005: TRIM 3 Manual (TRends \& Indices for Monitoring data). Statistics Netherlands, Voorburg, 58.

R Core Team 2014. R: A language and environment for statistical computing. R Foundation for Statistical Computing, Vienna, Austria. Retrieved April 17, 2015, from: http://www.R-project.org/.

Scheller W, Franke E, Matthes J, Neubauer M \& Schwarnber Ch 2001: Verbreitung, Bestandsentwicklung und Lebensraumsituation des Schreiadlers Aquila pomarina in Mecklenburg-Vorpommern. Vogelwelt 122: 233-246.

State Forest Service of Latvia 2015: Neliels ieskats vēsturē [A small insight into history]. Retrieved April 2, 2015, from: http://www.vmd.gov.lv/valsts-mezadienests/statiskas-lapas/zinas-par-iestadi/isa-ves- ture?nid $=848 \#$ jump.

Treinys R \& Dementavičius D 2004: Productivity and diet of lesser spotted eagle (Aquila pomarina) in Lithuania in 2001-2003. Acta Zoologica Lithuanica 14: 83-87.

Treinys R 2009: Habitat use and population status of the lesser spotted eagle Aquila pomarina on the northwestern periphery of the distribution range. Summary of doctoral dissertation. Vilnius University, Vilnius, 32.

Treinys R, Drobelis E, Šablevičius B, Naruševičius V \& Petraška A 2007: Changes in the abundance of the lesser spotted eagle (Aquila pomarina) breeding population in Lithuania in 1980-2006. Acta Zoologica Lithuanica 17: 64-69. DOI: 10.1080/ 13921657.2007.10512817.

Väli Ü 2012: Factors limiting reproductive performance and nestling sex ratio in the lesser spotted eagle Aquila pomarina at the northern limit of it range: the impact of weather and prey abundance. Acta Ornithologica 47: 157-168. DOI: 10.3161/ $000164512 \times 662269$.

Väli Ü 2015: Monitoring of spotted eagles in Estonia in 1994-2014: Stability of the lesser spotted eagle (Aquila pomarina) and decline of the greater spotted eagle (A. clanga). Slovak Raptor Journal 9: 55-64. DOI: 10.151 5/srj-201 5-0004.

Vrezec A, Duke G, Kovács A, Saurola P, Wernham Ch, Burfield I, Movalli P \& Bertoncelj I 2012: Overview of raptor monitoring activities in Europe. Acrocephalus 33: 154-155. DOI: 10.2478/v10100-012-0003-y. 